\title{
Transparency of Monetary Policy: Theory and Practice
}

\author{
Petra M. Geraats
}

October 2005

CWPE 0549

Not to be quoted without permission 


\title{
Transparency of Monetary Policy: Theory and Practice*
}

\author{
Petra M. Geraats ${ }^{\dagger}$ \\ University of Cambridge \\ October 2005
}

\begin{abstract}
Transparency has become one of the main features of monetary policymaking during the last decade. This paper establishes some stylized facts. In addition, it provides a systematic overview of the practice of monetary policy transparency around the world. It shows much diversity in information disclosure, even for central banks with the same monetary policy framework, including inflation targeting. Nevertheless, the paper finds significant differences in transparency across monetary policy frameworks. The empirical findings are explained using key insights distilled from the theoretical literature. Thus, this paper aims to bridge the gap between the theory and practice of monetary policy transparency.
\end{abstract}

Keywords: Transparency, monetary policy, central bank communication

JEL codes: E58, D82

* Part of this paper was written while the author was visiting the Center for Economic Studies (CES) in Munich, which I thank for its hospitality.

${ }^{\dagger}$ Faculty of Economics, University of Cambridge, Cambridge, CB3 9DD, United Kingdom. Email: Petra.Geraats@econ.cam.ac.uk. 


\section{Introduction}

Transparency has become one of the main features of monetary policymaking during the last decade. The advance of transparency has been accompanied by a burgeoning theoretical literature. However, there is still a large gap between the theory and practice of monetary policy transparency. This paper formulates stylized facts on the transparency of central banks. Furthermore, it provides a systematic overview of transparency practices around the world, which shows how the extent of information disclosure by central banks depends on the monetary policy framework and on the particular aspect of the monetary policymaking process that is involved. The empirical findings are explained using key insights distilled from the large variety of theoretical results in the literature. Thus, the paper reconciles the theory and practice of monetary policy transparency.

In theory, transparency refers to a situation of symmetric information. Reductions in information asymmetries between monetary policymakers and the private sector improve the transparency of monetary policy. The consequences of greater transparency depend on the specific context and are not necessarily positive. But in general there are two kinds of effects, namely ex post 'information effects' that are directly based on the disclosed information, and ex ante 'incentive effects' that structurally alter economic behavior based on the new information structure. These effects, which are in the spirit of Geraats (2002), are further explained in section 2 and are used throughout the paper to explain the empirical findings.

The main contribution of this paper is to present three stylized facts on the practice of monetary policy transparency. In particular, in section 3 it is established that (I) central banks consider transparency very important for monetary policy, (II) transparency of monetary policy has increased remarkably during the last 15 years, and (III) monetary policy transparency displays substantial heterogeneity both across and within monetary policy frameworks.

This third empirical finding is a major theme of this paper that is further developed in the systematic overview of the practice of monetary policy transparency throughout the world in section 4. This overview presents more detailed empirical facts covering the four main components of the monetary policymaking process, namely the institutions and formal objectives that shape monetary policy preferences (section 4.1), the economic conditions that determine the constraints faced by policymakers (section 4.2), the monetary policy strategy and decision process that form some kind of decision rule (section 4.3), and the monetary policy stance that is the outcome of the decision-making process (section 4.4).

The facts on transparency practices highlight that there are some aspects of the policymaking process for which there is a fair amount of transparency in a large majority of countries, including central bank independence, monetary policy targets, forward-looking analysis and explanations of policy changes. However, there are also several issues about which central banks are largely opaque, including minutes, voting records and explanations of policy decisions not to adjust policy settings.

In addition to these differences in transparency across monetary policy aspects, there is also a lot of variety across monetary policy frameworks. In particular, exchange rate targeters are often 
considerably less transparent than others, whereas inflation targeters tend to be significantly more transparent. Although the adoption of inflation targeting by many countries has contributed to the rise in central bank transparency, this paper makes clear that inflation targeting is neither a necessary nor a sufficient condition for transparency. In fact, there is remarkable variation in transparency practices among inflation targeters.

The paper discusses two other issues relevant for transparency practices. It argues that transparency is not solely driven by accountability requirements (section 5.1). In addition, it addresses communication challenges (section 5.2). The conclusions of the paper are summarized in section 6.

There is a rapidly expanding literature on transparency of monetary policy. A systematic survey of this literature is provided by Geraats (2002). In addition, there is an increasing amount of empirical research that estimates the economic effects of monetary policy transparency. The results so far largely suggest that greater transparency tends to be beneficial for monetary policy. In particular, there is econometric evidence that monetary policy transparency reduces average inflation (Chortareas, Stasavage and Sterne 2002), lowers the sacrifice ratio (Chortareas, Stasavage and Sterne 2003), and improves the predictability of monetary policy actions (e.g. Gerlach-Kristen 2004). The present paper contributes to the transparency literature by systematically exploring the practice of central bank transparency and reconciling it with theoretical insights.

\section{Theoretical Insights}

Transparency of monetary policy refers to the absence of information asymmetries between monetary policymakers and the private sector (e.g. Geraats 2002). Perfect transparency corresponds to a situation of symmetric information. This does not imply that monetary policymakers and the private sector have complete information. For instance, they could both be uncertain about economic disturbances. But perfect transparency means that both face the same information and uncertainties.

It is easy to see that greater transparency could be beneficial since the private sector gets access to more information. In fact, in an economy with no market imperfections besides an information asymmetry, perfect transparency is optimal by the first welfare theorem. However, an increase in transparency could be detrimental in richer, more realistic settings.

To better understand the consequences of transparency it is fruitful to distinguish two basic effects, which I label here as 'information effects' and 'incentive effects'. ${ }^{1}$ Information effects are the direct, ex post effects of the information disclosure. In particular, when the central bank (the sender) reveals information to the private sector (the receiver), the central bank no longer has the opportunity to use its information advantage and the private sector gets access to new information to act upon. Incentive effects are the indirect, ex ante structural changes in economic behavior that result from the different information structure under greater transparency. In particular, anticipating the disclosure of a particular type of information, the central bank and/or

\footnotetext{
${ }^{1}$ They are similar to the effects described by Geraats (2002), except for being more general and sophisticated.
} 
private sector could face incentives to structurally alter their behavior. It should be stressed that the information and incentive effects of an increase in transparency need not be beneficial but could actually be detrimental.

Regarding information effects, the receiver of the information always enjoys a direct benefit because (s)he faces less uncertainty and has the opportunity to make better informed decisions. The new information also leads to an adjustment of the receiver's expectations, which could affect other economic variables, possibly in undesirable ways. In addition, the communications of the sender may be misunderstood by the receiver, which gives rise to unintended noise.

To give some examples of information effects, transparency about the central bank's preferences makes monetary policy more predictable for the private sector. But the communication of central bank targets could affect inflation expectations and make inflation more volatile, which is exacerbated by misinterpretations (Geraats 2005a). The disclosure of supply shocks could have a similar negative information effect.

In addition, a central bank with an exchange rate peg would be ill-advised to announce that its foreign reserves are running low since it is bound to incite a speculative attack. Similarly, a central bank would be prudent to keep liquidity problems of commercial banks confidential to prevent bank runs. Such 'ex post discretionary disclosures' give rise to detrimental information effects that could imperil financial stability (Gai and Shin 2003). However, 'ex ante communication' of such information in the form of regularly scheduled data releases on foreign reserves and liquidity positions could encourage prudent behavior that reduces the likelihood of financial fragility, which is a beneficial incentive effect.

The incentive effects of transparency could affect the economic behavior of both the sender and receiver of information. In particular, in response to the new information structure the receiver could modify the formation of its expectations. In turn, the change in responsiveness of the receiver's expectations could affect the sender's behavior. Suppose that the private sector cannot observe the central bank's preferences but attempts to infer them from monetary policy actions and outcomes. When there is greater transparency about the economic shocks affecting policy actions and outcomes, private sector expectations optimally become more sensitive to unanticipated changes in policy actions and outcomes as they provide a more accurate signal of the central bank's preferences. The stronger response of inflation expectations makes the pursuit of inflationary preferences more costly, so that the central bank has a greater incentive to keep inflation in check. Stated differently, transparency induces the central bank to build and maintain a reputation for low inflation (e.g. Faust and Svensson 2001, Geraats 2005b).

However, the response of the receiver could also have detrimental incentive effects. Suppose that economic agents with private signals have a motive to coordinate their actions (such as in financial markets) and therefore put a disproportionately high weight on a public signal sent by the central bank. Then, greater central bank transparency increases the reliance on the public signal even further, which could lead to greater volatility when the public signal is sufficiently noisy (Morris and Shin 2002). The increased focus on public communications due to a coordination motive also reduces the informativeness of market signals (Shin and Morris 2005). In addition, public disclosure could crowd out private sector efforts to acquire their own infor- 
mation and thereby reduce the net improvement in forecast accuracy (Tong 2005). Similar in spirit, less secrecy makes it less costly for financial market participants to engage in central bank watching, which could increase volatility due to overreactions (Rudin 1988).

Finally, public disclosure could have another incentive effect by increasing the sender's efforts to improve the quality of its information so that it can withstand public scrutiny. For instance, the publication of central bank forecasts could induce the central bank to produce first rate macroeconomic projections. Similarly, the release of the minutes of monetary policy meetings could stimulate central bankers to engage in a high quality policy discussion. Thus, transparency could lead to better decision making.

These theoretical arguments give rise to three key results of the effects of monetary policy transparency on predictability, reputation and credibility.

\section{(A) Transparency improves the predictability of monetary policy actions and outcomes.}

This follows directly from the information effect that transparency reduces private sector uncertainty about the monetary policymaking process. A better understanding of the monetary policy objectives, strategy and decision-making process, combined with information about economic disturbances helps the private sector to better forecast the settings of the policy instrument and the effects on inflation and aggregate output. Empirically, greater monetary policy transparency indeed appears to lead to better predictability of monetary policy actions (e.g. GerlachKristen 2004, Swanson 2004).

Although in theory, greater transparency improves predictability (ceteris paribus), it could be misleading to use private sector forecast errors or market reactions to monetary policy decisions as a measure of lack of central bank transparency. The reason is that predictability is also determined by economic disturbances. When there are no major shocks to the economy, monetary policy is likely to be more predictable even in the absence of improved central bank communication. So, better predictability need not be the consequence of greater transparency.

(B) Transparency induces reputation building as it increases the sensitivity of private sector expectations to unanticipated policy actions and outcomes.

This incentive effect follows from the fact that transparency makes monetary policy actions and outcomes a better signal of the central bank's intentions. ${ }^{2}$ The greater sensitivity of private sector expectations makes it less costly for a high-inflation central bank to build reputation through contractionary policies. In addition, a central bank that attempts to boost output beyond its natural rate would quickly be exposed and be penalized through higher inflation expectations. As a result, transparency makes central banks more inclined to pursue low inflation and lowers the sacrifice ratio associated with disinflations. There is indeed econometric evidence that supports this (Chortareas et al. 2002, 2003).

(C) Transparency enhances credibility and makes long-run private sector inflation expectations more stable.

\footnotetext{
${ }^{2}$ To be precise, this relies on the plausible assumption that there is some uncertainty about monetary policy preferences, which inherently cannot be directly observed. So, the effect does not apply to perfect preference transparency.
} 
Transparency allows the private sector to check whether monetary policy actions and outcomes are consistent with formal monetary policy objectives, which increases the credibility of monetary policy. Besides this information effect, there is an incentive effect as the private sector becomes more assured of the central bank's good intentions, which reduces its sensitivity to policy actions and outcomes. As a consequence, transparency helps to anchor long-run inflation expectations. ${ }^{3}$ Empirical evidence indicates that greater transparency indeed makes private sector inflation expectations less sensitive to past inflation outcomes (van der Cruijsen and Demertzis 2005).

This outlines the main theoretical effects of transparency. A more detailed and comprehensive survey of the theory of central bank transparency is provided by Geraats (2002).

\section{Stylized Facts}

The practice of monetary policy transparency is very diverse and still evolving over time. Nevertheless, three empirical facts can be identified:

I Central banks consider transparency very important for monetary policy.

II Transparency of monetary policy has increased remarkably during the last 15 years.

III Monetary policy transparency displays substantial heterogeneity both across and within monetary policy frameworks.

It is useful to formally substantiate each of these stylized facts.

\section{Central banks consider transparency very important for monetary policy.}

In a wide-ranging survey of 94 central banks in 1998 by Fry, Julius, Mahadeva, Roger and Sterne (2000), 74\% of central banks consider transparency a 'vital' or 'very important' component of their monetary policy framework. The only two factors that were rated higher were independence of the central bank and the maintenance of low inflation expectations, which were considered vital or very important by $83 \%$ and $82 \%$, respectively (Fry et al. 2000, Table 8.1 ). However, the importance attached to transparency is not shared equally among central banks. Although transparency ranked third for industrialized countries (just as for the entire sample), transitional and especially developing countries rated transparency lower. In particular, 50\% of central banks from industrialized countries considered transparency vital, but only $29 \%$ from transitional and developing countries.

It is often argued that there are two key reasons for transparency: democratic accountability and economic benefits (e.g. Blinder, Goodhart, Hildebrand, Lipton and Wyplosz 2001). First, transparency is necessary for accountability, which is used to ensure the democratic legitimacy

\footnotetext{
${ }^{3}$ This is based on the plausible assumption that long-run monetary policy objectives are stable. Otherwise, inflation expectations could become more volatile as they track the objectives more closely under transparency.
} 
of monetary policy. This is especially relevant for central banks that enjoy operational independence. This may explain the marked difference in the importance of transparency for central bankers. According to the survey by Fry et al. (2000, Table 4.4), 57\% of central banks from industrialized countries report that they can formulate and implement policy independently without any government constraint, whereas this applies to only $30 \%$ from transitional and developing countries. In addition, there is a strong, highly significant correlation of +0.42 between the measures for 'independence' and 'policy explanations' constructed by Fry et al. (2000). This confirms that there is a positive relation between central bank independence and transparency.

The other main rationale for transparency is its economic benefits. As explained in section 2, transparency reduces private sector uncertainty and enhances the predictability of monetary policy. Furthermore, it could give central banks a stronger incentive to build reputation. It could also be good for credibility. This is clear from the survey by Blinder (2000, Table 2), in which 88 central bankers indicated that important factors to establish or maintain credibility are (i) a history of honesty, (ii) central bank independence, (iii) a history of fighting inflation, and (iv) transparency, where the latter two get nearly the same average rating. This provides another reason why the great majority of central banks consider transparency very important.

\section{Transparency of monetary policy has increased remarkably during the last 15 years.}

The most prominent way in which the increase in transparency of monetary policy has materialized is through the adoption of 'inflation targeting' by an increasing number of central banks. Inflation targeting could be defined as a monetary policy framework that involves an institutional commitment to price stability that focuses on an explicit quantitative target for inflation as the nominal anchor for monetary policy. Sometimes it is referred to as 'direct' or 'explicit' inflation targeting since other monetary policy frameworks such as exchange rate or monetary targeting generally target inflation implicitly and/or indirectly through an intermediate target. The institutional commitment to price stability typically consists of central bank independence together with accountability requirements and a high degree of transparency through regular central bank publications.

The pioneer of inflation targeting was New Zealand, where the Reserve Bank of New Zealand Act of 1989 and the Policy Targets Agreement of March 1990 provided the institutional foundations of its new monetary policy framework. Other early adopters of inflation targeting were Canada (in 1991), the United Kingdom (in 1992), Sweden (in 1993), Finland (from 1993 until 1998), Australia (in 1994) and Spain (from 1994 until 1998). ${ }^{4}$ In addition, a few emerging countries in the process of disinflation introduced annual inflation targets without immediately adopting full-fledged inflation targeting, namely Chile (in 1991), Israel (in 1992) and Peru (in 1994).

Inflation targeting became more widespread in the late 1990s as it proved popular with emerging countries that were looking for a new monetary policy framework after abandoning fixed exchange rate regimes. The number of inflation targeters has steadily grown over time to more than 20 and now also includes Brazil, Colombia, Czech Republic, Hungary, Iceland, Mex-

\footnotetext{
${ }^{4}$ Finland and Spain had to abandon inflation targeting to join the European Monetary Union (EMU) in 1998.
} 
ico, Norway, Philippines, Poland, South Africa, South Korea, Switzerland and Thailand. ${ }^{5}$ This advance of inflation targeting has contributed considerably to greater transparency of monetary policy.

However, the increase in transparency has not been confined to the adoption of inflation targeting. More generally, the use of explicit targets and monitoring ranges for inflation, money or the exchange rate has quickly expanded from only 43 (out of 84 surveyed) countries in 1990 to 89 (out of 93) in 1998 (Fry et al. 2000, Table 3.1), which corresponds to an increase in the relative frequency from $51.2 \%$ to $95.7 \%$. Furthermore, transparency has also improved in other respects as is evident from the central bank transparency index by Eijffinger and Geraats (2004), which provides a measure of the disclosure of information pertinent to monetary policymaking. The index is available for nine major central banks from 1998 to 2002 and it shows a significant average rise in transparency. Most of this appears to be attributable to improved disclosure of economic information such as the central bank's macroeconomic forecasts and policy models. The biggest increases in the transparency index were for Sweden and New Zealand, which were already experienced inflation targeters. But there were also notable rises in transparency for the European Central Bank (ECB) and the US Federal Reserve. This shows that the advance of transparency is a more general phenomenon that goes beyond the adoption of inflation targeting.

The fact that monetary policy transparency has increased may be related to institutional reforms in many countries that have enhanced central bank independence and reinforced accountability. But the openness displayed by most central banks by far exceeds formal accountability requirements. This suggests that central banks have adopted greater transparency primarily because of perceived economic benefits.

III Monetary policy transparency displays substantial heterogeneity both across and within monetary policy frameworks.

There are large variations in the degree of transparency. In particular, it depends on the kind of information involved and differs significantly across monetary policy frameworks, but there is also much variation in transparency for central banks that share the same monetary policy framework. These facts are clear from Table 1, which reports the relative frequency of transparency about several issues across the 94 central banks surveyed by Fry et al. (2000). ${ }^{6}$ The first column shows that it is very common to publish a specific target, to provide an explanation of policy changes on the day of a change to the monetary policy instrument, and to include forecasts or other forward-looking analysis in regular central bank reports and bulletins. In particular, this occurs for $88 \%, 81 \%$ and $78 \%$ of surveyed central banks, respectively. In addition, $67 \%$ of central banks enjoy instrument independence in the sense that the central bank decides on the adjustment of monetary policy instruments, without any government representative attending

\footnotetext{
${ }^{5}$ Although the Swiss central bank has stated not to be an inflation targeter, it is often included (e.g. SchmidtHebbel and Tapia 2002, Fracasso, Genberg and Wyplosz 2003) and its monetary policy framework is consistent with the definition of inflation targeting provided above.

${ }^{6}$ There are some missing observations in the Fry et al. (2000) data appendix, some of which could be recovered from additional information in their study. An attempt to fill in the remaining missing information for Denmark, the EMU and Singapore gives results very similar to those in Tables 1, 3 and 4.
} 
Table 1: Monetary policy transparency across and within monetary policy frameworks.

\begin{tabular}{lcccccc}
\hline Relative frequency & Full sample & \multicolumn{3}{c}{ Targeting } & Other & $\begin{array}{c}\text { Homogeneity } \\
\text { rejected }\end{array}$ \\
\hline Publication of & & Exch. rate & Money & Inflation $^{a}$ & & ** \\
$\quad$ Target & 0.883 & 0.962 & 0.913 & 0.933 & $\mathbf{0 . 7 6 7}$ & $* *$ \\
Forecasts $^{b}$ & 0.780 & $\mathbf{0 . 6 6 7}$ & 0.870 & $\mathbf{0 . 9 3 3}$ & 0.724 & $*$ \\
Minutes $^{b}$ & 0.176 & 0.083 & 0.087 & $\mathbf{0 . 6 0 0}$ & 0.103 & $* * *$ \\
$\quad$ Voting records & 0.064 & 0.000 & 0.043 & $\mathbf{0 . 2 0 0}$ & 0.067 & $* *$ \\
$\quad$ Policy change explanations & 0.809 & 0.808 & $\mathbf{0 . 6 9 6}$ & $\mathbf{0 . 9 3 3}$ & 0.833 & $* *$ \\
Instrument independence & 0.670 & 0.692 & 0.696 & 0.733 & 0.600 & - \\
& & & & & & \\
Observations & $94\left(91^{b}\right)$ & $26\left(24^{b}\right)$ & 23 & 15 & $30\left(29^{b}\right)$ & \\
\hline
\end{tabular}

Source: Author's calculations using Fry et al. (2000) survey data.

Note: Numbers in bold differ more than 10 percent point from the relative frequency in the full sample. a) $\chi_{1}^{2}$ test of homogeneity between monetary policy frameworks rejected at a significance level of (*) $10 \%,(* *) 5 \%$ or $(* * *) 1 \%$.

b) Missing observations for Denmark, EMU and Singapore.

the monetary policy meeting other than as an observer. However, the minutes or a summary discussion of monetary policy meetings are published by only $18 \%$ of central banks, and voting records or patterns are released by a meager $6 \% .^{7}$ These results show that central banks are not transparent in all respects. This also follows from the detailed transparency data collected by Eijffinger and Geraats (2004), which covers fifteen different items for nine major central banks.

The other four columns in Table 1 show that the heterogeneity in relative frequencies persists when focusing on central banks with the same monetary policy framework. The classification is based on the Fry et al. (2000) survey conducted in 1998, which asked each central bank to categorize its monetary policy framework as 'exchange rate targeting', 'money targeting', 'inflation targeting', or another framework. Each monetary policy regime appears to have its own transparency characteristics. In particular, exchange rate targeters generally publish the target but not minutes and voting records. Monetary targeters typically do not release minutes and voting records either, but they tend to disclose forecasts in addition to the target. Inflation targeters are generally transparent about the target and forecasts, as well as policy change explanations. The other central banks have in common that they do not tend to provide minutes and voting records. In all other respects, there is quite some variation in transparency among the central banks within each framework.

Interestingly, this heterogeneity in disclosure practices extends to inflation targeters. This is confirmed by the Eijffinger and Geraats (2004) data, which makes clear that clarity about the objective of price stability with a numeric target for inflation are common features of inflation targeting, but there is considerable diversity in transparency about central bank forecasts, policy

\footnotetext{
${ }^{7}$ Note that minutes and voting records do not exist when monetary policy decisions are made solely by the central bank governor, which is further discussed in section 4.3.
} 
decision explanations, policy inclinations, minutes, voting records, unanticipated transmission disturbances and policy evaluations. This shows that inflation targeting by no means implies transparency about all aspects of the monetary policymaking process.

The rows in Table 1 show for each transparency item the differences across monetary policy frameworks, where relative frequencies that differ more than 10 percent point from the full sample are highlighted in bold. Furthermore, the last column in Table 1 reports for each item whether there is a statistically significant difference in the relative frequency between monetary policy regimes using a homogeneity test. ${ }^{8}$ This gives rise to several findings.

First of all, the relative frequency of a published target is significantly less for central banks that do not engage in one of the three targeting frameworks. In other words, central banks with a targeting framework are more likely to have an explicit target, which is not surprising.

More interesting is the fact that transparency about forecasts is considerably less frequent for exchange rate targeters but prevalent among inflation targeters. The difference between the two is statistically significant. Homogeneity is even more firmly rejected when money targeters are combined with inflation targeters and exchange rate targeters with others. ${ }^{9}$ This difference reflects the greater need for forward-looking analysis in monetary and especially inflation targeting.

Another striking result is that inflation targeters are much more likely to publish minutes and voting records. Perhaps, openness about the decision process is more important because inflation targeting is more involved, whereas exchange rate and monetary targets can be more directly controlled.

Finally, although a great majority of central banks provides a prompt explanation for policy changes, it is less common under monetary targeting but nearly universal under inflation targeting. The difference between the latter two is statistically significant, but it appears to be driven by opaque monetary targeters in developing countries.

The overview in Table 1 clearly establishes that there is significant heterogeneity in transparency across monetary policy frameworks. In particular, inflation targeters are most likely to be transparent, whereas opacity is more common among exchange rate targeters and central banks without a targeting framework. The diversity in information disclosure is also evident from the next section, which takes a more detailed and systematic look at the practice of central bank transparency.

\section{Transparency in Practice}

To further analyze transparency practices it is useful to distinguish the key components of the monetary policymaking process. In practice, monetary policymaking is a very elaborate process,

\footnotetext{
${ }^{8}$ More precisely, a $\chi_{1}^{2}$ test of homogeneity is used to test for each transparency item whether the relative frequency in bold equals the aggregate relative frequency of the other three frameworks, or in case of two bold relative frequencies, whether they are equal to each other.

${ }^{9}$ The $\mathrm{p}$-value of the $\chi_{1}^{2}$ test of homogeneity between money and inflation targeters versus exchange rate targeters and others equals 0.025 .
} 
but conceptually it can be described by policymakers' preferences, economic constraints and a decision rule, which result in a policy decision. The preferences of monetary policymakers are shaped by institutional arrangements and formal objectives. The economic conditions faced by policymakers are determined by the structure of the economy and economic disturbances. The decision rule is given by the monetary policy strategy, which explains abstractly how preferences and economic information are combined to formulate a monetary policy decision. This decision making process results in the monetary policy stance. Each of these components is critical to understanding the monetary policymaking process. The remainder of this section discusses transparency practices for each component, namely institutions and objectives in section 4.1, economic conditions in section 4.2, strategy and decision-making in section 4.3, and the policy stance in section 4.4. ${ }^{10}$

Detailed information on the transparency practices of central banks can be obtained from several sources. There is extensive documentation for inflation targeters, including Bernanke, Laubach, Mishkin and Posen (1999), Schaechter, Stone and Zelmer (2000), Schmidt-Hebbel and Tapia (2002) and Fracasso, Genberg and Wyplosz (2003). There are only a few elaborate studies on the practice of monetary policy transparency that are not confined to inflation targeting, namely Fry, Julius, Mahadeva, Roger and Sterne (2000), Blinder, Goodhart, Hildebrand, Lipton and Wyplosz (2001) and Eijffinger and Geraats (2004). In addition, central bank web sites are an invaluable source of up-to-date information.

\subsection{Institutions and Objectives}

The policy preferences that drive monetary policy decisions are determined by who the policymakers are and what institutional arrangements and policy objectives they face. When monetary policy is run by the government it is prone to the whims of politicians with electoral concerns. Such fickle, political interests lead to uncertainty about monetary policy objectives. This can be avoided by delegating monetary policy to an independent central bank with formal monetary policy objectives. Thus, central bank independence enhances transparency since it isolates monetary policymakers from political pressures.

In practice, central bank independence is very common. In the survey by Fry et al. (2000, Table 4.4), 71\% of central banks report that they enjoy independence without significant qualifications. However, in developing countries this holds for only $57 \%$ of central banks. ${ }^{11}$

Central bank independence appears to be determined by several institutional characteristics. The degree of independence reported by central banks in the survey by Fry et al. (2000, Table 6.1) is strongly positively correlated with limits on monetary financing of the government budget deficit and the degree of instrument independence. It also shows a significant, positive

\footnotetext{
${ }^{10}$ This structure is similar to Geraats (2002), who distinguishes the 'political', 'economic', 'procedural', 'policy' and 'operational' aspects of the policymaking process. Although that distinction makes it easier to understand all the subtleties of the theoretical transparency literature, the present framework is more useful for the practice of monetary policy transparency.

${ }^{11}$ Data on this issue is not available for individual central banks, which precludes a comparison across monetary policy regimes.
} 
Table 2: Central bank independence and its key determinants.

\begin{tabular}{lcc}
\hline Relative frequency & Full sample & $\begin{array}{c}\text { Developing } \\
\text { countries }\end{array}$ \\
\hline Independence without significant qualifications & $71 \%$ & $57 \%$ \\
Effective limits on monetary financing of fiscal deficits & $65 \%$ & $41 \%$ \\
Instrument independence & $67 \%$ & $50 \%$ \\
Long term of central bank governor ( $\geq 5$ years) & $79 \%$ & $70 \%$ \\
& & \\
Observations & 94 & 44 \\
\hline Source: Fry et al. (2000, Table 4.4) and author's calculations. & &
\end{tabular}

correlation with the length of the term of office of the central bank governor.

Table 2 shows the frequency of central bank independence and its key institutional characteristics for the full sample of 94 countries and the 44 developing countries in the Fry et al. (2000) survey. Effective limits on monetary financing of fiscal deficits, in the form of wellenforced prohibitions or narrow limits, are in place for $65 \%$ of the full sample, but only $41 \%$ of developing countries. Such financing limits are important to prevent hyperinflation caused by the reliance on seignorage to extract government revenue. In $67 \%$ of the full sample but only $50 \%$ of developing countries, the central bank has instrument independence in the sense that it can determine the adjustment of monetary policy instruments without government interference. A long term of office of the central bank governor of at least five years is present in a large majority, namely $79 \%$ of countries, including $70 \%$ of developing countries. A term of office that exceeds the length of the electoral cycle is useful to reduce political influence through the (re)appointment of central bankers.

It is clear from Table 2 that in most countries, but to a lesser extent in developing countries, the central bank enjoys independence. The most popular theoretical motivation for central bank independence is based on the time-inconsistency problem in rational expectations models in which monetary policymakers attempt to stimulate output beyond its natural rate (Kydland and Prescott 1977). The resulting inflation bias can be reduced by delegating monetary policy to a 'conservative' central banker that puts greater weight on inflation stabilization, but it comes at the cost of greater output variability (Rogoff 1985). In practice, the inflation bias appears to be eliminated by the delegation of monetary policy to 'responsible' central bankers that aim to stabilize output around its natural rate (Blinder 1997).

Central bank independence facilitates monetary policy transparency because it allows the central bank to pursue the monetary policy objectives without undue political pressures. Generally, monetary policy objectives focus (directly or indirectly) on price stability. The use of explicit targets for monetary policy is prevalent nowadays. Only 5 (out of 93) central banks in the survey by Fry et al. (2000) report that they do not have an explicit exchange rate, money or inflation target. However, exchange rate and money targets tend to be operational or interme- 
diate targets and do not convey the central bank's ultimate objectives. In that respect, inflation targets are more informative and they are published by 55 (out of 93) countries (Fry et al. 2000, Table A.4). However, in 36 countries the inflation target is set for a period of only one year or revised more than annually. Considering the substantial lag with which monetary policy actions affect inflation, these short term inflation targets are more similar to inflation projections rather than an indication of policy preferences. Only 18 (out of 93) countries have a long run inflation target (Fry et al. 2000, Chart 3.6), which shows that transparency is not so common in this respect.

There is some variation in the design of inflation targets as shown by Mishkin and SchmidtHebbel (2002, Table 2), who focus on inflation targeters. The inflation target could be determined by the government, the central bank or jointly. The measure of inflation tends to be the one-year change in the consumer price index or some core measure that excludes certain factors such as indirect taxes and interest charges. The target is often in the form of a range (of about two percentage points) or a point with some tolerance range. In addition, a few countries have escape clauses that specify when deviations from the target are permitted. The target horizon is typically indefinite for advanced countries, but emerging countries on a path of disinflation generally use a one-year horizon to maintain flexibility.

The inflation target is by no means a complete description of the central bank's objectives. Other variables are likely to matter as well, such as output or financial stability. Complete transparency about monetary policymakers' preferences would require knowledge about all the variables in their implicit 'loss function', the target for each variable, the functional form of the loss function, and the relative weight attached to each variable.

In practice, central banks are extremely opaque about these other features of the monetary policy loss function, with two exceptions. First, central banks with a point target for inflation often have an explicit tolerance margin around the target, which is typically plus/minus one percent point. This suggests a symmetric concern about deviations of inflation from the target.

Second, in many countries price stability is not the sole objective or concern of monetary policy. Some central banks formally have multiple goals. For instance, the US Federal Reserve Act (section 2A) stipulates the goals of "maximum employment, stable prices, and moderate long-term interest rates". In addition, most inflation targeters that have the primary goal of price stability acknowledge that they also care about stability of the real economy and/or the financial sector. So, inflation targeters are by no means 'inflation nutters' that single-mindedly practice 'strict inflation targeting' with the sole objective of inflation stabilization, but instead they engage in 'flexible inflation targeting'. However, inflation targeters are not precise about the weight they attach to inflation stabilization versus output stabilization, although empirical evidence suggests that the adoption of inflation targeting tends to increase the relative weight that the central bank places on inflation stabilization (Cecchetti and Ehrmann 2002).

Although transparency about the monetary policy loss function would lead to a beneficial information effect as it reduces private sector uncertainty, the theoretical literature provides a number of reasons why opacity may be desirable.

Regarding policy targets, the communication of the output target could affect inflation ex- 
pectations. This makes it more difficult to reach the output target and the greater variability of inflation expectations hampers the stabilization of inflation (Geraats 2005a). In addition, it is better to be silent about an output target that exceeds the natural rate of output, because it would lead to an inflation bias, as mentioned above. Furthermore, when the level of the target is highly uncertain (e.g. the natural rate of output, or fundamental asset prices) and the central bank is unlikely to have superior information about it compared to the private sector, disclosure of the target could cause financial market participants to ignore their private information and coordinate on the noisy disclosed target, leading to greater volatility (cf Morris and Shin 2002).

With respect to the functional form, monetary policymakers benefit from not admitting to an asymmetric output objective that puts greater weight on output losses, because it leads to a bias in average inflation. One reason is that the output preference asymmetry makes the optimal inflation response to output supply shocks convex (Geraats 1999). Another reason is that it induces 'precautionary' output expansions when the central bank faces uncertainty about supply shocks (Cukierman 2002). So, transparency about the preference asymmetry causes the private sector to rationally increase its inflation expectations, which exacerbates the inflation bias.

Concerning the policy weights, uncertainty about the weight the central bank places on inflation stabilization versus output stabilization could be beneficial as it induces a risk averse union to moderate its wage demands, thereby reducing inflation and boosting output (Sørensen 1991).

Finally, some uncertainty about the central bank's preferences gives the central bank a beneficial incentive to invest in reputation. Direct observability of the central bank's goals could be highly damaging because it makes the public less sensitive to monetary policy actions and outcomes, which makes it more tempting for the central bank to pursue expansionary policy that leads to an inflation bias (Faust and Svensson 2001, Geraats 2005b).

Besides these theoretical arguments, there are some practical issues associated with transparency about the monetary policy loss function. First, monetary policy decisions are often made by a committee, which raises the question how to aggregate the loss functions of individual committee members into a committee loss function. Svensson (2003) proposes to agree on some reasonable choices, namely a loss function that is quadratic in the deviation of inflation from its target and in the output gap. The weight in the loss function could be set equal to the weight of the median committee member.

Another issue is whether the weight on inflation versus output stabilization is independent of other economic variables. For instance, the central bank may be more concerned about output volatility when unemployment is high or the financial sector fragile. In that case, the marginal rate of substitution between inflation and output depends on those other factors as well, so the weight is not constant.

This last complication could be overcome by communicating the relative weight on inflation versus output stabilization in a different fashion. The relative weight matters most when inflation deviates significantly from its target, since the preference weight determines the speed at which inflation optimally returns to the target (Svensson 1997). So, the central bank could indicate the projected time path for inflation whenever a substantial deviation from target arises (e.g. after 
a major economic shock or during a period of disinflation). In fact, many central banks are required to do so as part of formal procedures when the target is missed. This approach is more practical than attempting to agree on and communicate the preference weight more generally.

To summarize, a closer look reveals that transparency of monetary policy preferences is quite limited in practice. Although central bank independence is very common and explicit nominal targets are ubiquitous, relatively few countries publish a long term, numeric target for inflation and there is much opacity about possible real targets, asymmetric objectives and policy weights.

\subsection{Economic Conditions}

The economic constraints that monetary policymakers face are determined by the structure of the economy and economic disturbances. So, economic information is a vital input in the policymaking process. Transparency requires the disclosure of all economic information relevant to monetary policy, including economic statistics, central bank forecasts and policy models.

Monetary policymakers generally examine a large amount of economic data before they make a policy decision. The economic statistics they consider are largely publicly available. One exception is confidential bank supervisory information, which has been shown to affect monetary policy decisions (Peek, Rosengren and Tootell 1999). However, the most important source of asymmetric information between the central bank and the private sector stems from the interpretation of the economic data. In particular, the central bank could have different economic models and forecasts than the private sector. It is plausible that a central bank, which typically employs a large number of $\mathrm{PhD}$ economists, uses a more sophisticated economic model and has more detailed forecasts than financial market participants, which each have much more limited resources. In fact, Romer and Romer (2000) have shown that confidential Federal Reserve staff forecasts are superior to commercial forecasts, even at short horizons.

Macroeconomic forecasts are important because the monetary policy instrument cannot immediately affect inflation. Typically, there is a transmission lag of one to two years, which makes a forward-looking approach necessary for monetary policy. Table 3 shows that over $75 \%$ of central banks publish forward-looking analysis. However, more detailed forward-looking analysis is far less common. In particular, only $41 \%$ of central banks release forecasts that are published more than annually. Frequent forecasts are important because macroeconomic conditions could change significantly in the course of a year. In addition, quantitative forecasts in the form of numbers and/or graphs provide greater clarity but are provided by only $37 \%$ of central banks. Although assessments of risks to forecasts give a useful indication of uncertainties, only $34 \%$ of central bank publishes them in any (qualitative or quantitative) form. Finally, forecasts errors, which explain why well-intended monetary policy actions may not have obtained the desired macroeconomic outcomes, are disclosed by less than a third of central banks.

The extent to which forecasts are published appears to depend on the monetary policy framework. Table 1 already established that inflation and monetary targeters are more likely to publish forward-looking analysis than exchange rate targeters and others. Table 3 further confirms that inflation targeters clearly distinguish themselves from others in forecast transparency. In partic- 
Table 3: Forecast transparency across and within monetary policy frameworks.

\begin{tabular}{lcccccc}
\hline Relative frequency & Full sample & Exch. rate & $\begin{array}{c}\text { Targeting } \\
\text { Money }\end{array}$ & Inflation & Other & \begin{tabular}{c} 
Homogeneity $^{\text {rejected }^{a}}$ \\
\hline Publication of
\end{tabular} \\
$\quad$ Forecasts & 0.780 & $\mathbf{0 . 6 6 7}$ & 0.870 & $\mathbf{0 . 9 3 3}$ & 0.724 & $*$ \\
$\quad$ Frequent forecasts & 0.407 & 0.417 & 0.348 & $\mathbf{0 . 6 0 0}$ & 0.345 & $*$ \\
$\quad$ Quantitative forecasts & 0.374 & 0.417 & 0.391 & $\mathbf{0 . 2 6 7}$ & 0.379 & - \\
$\quad$ Risks to forecasts & 0.341 & 0.391 & 0.261 & $\mathbf{0 . 4 6 7}$ & 0.310 & - \\
$\quad$ Forecast errors & 0.319 & 0.261 & 0.261 & $\mathbf{0 . 6 0 0}$ & 0.276 & $*$ \\
& & & & & & \\
Observations & 91 & 24 & 23 & 15 & 29 & \\
\hline
\end{tabular}

Source: Author's calculations using Fry et al. (2000) survey data.

Note: Numbers in bold are over 10 percent point different from the full sample relative frequency.

a) $\chi_{1}^{2}$ test of homogeneity between monetary policy frameworks rejected at a significance level of $(*)$ $10 \%$ or $(* *) 5 \%$.

ular, they are significantly more likely to release frequent forecasts and discuss forecast errors. The publication of risks to forecasts is also more common among inflation targeters, but this result is not statistically significant. Perhaps surprisingly, although virtually all inflation targeters publish some kind of forecasts, the disclosure of quantitative forecasts is relatively rare. In fact, it occurs less frequently for the inflation targeters in the Fry et al. (2000) survey than for others, although this difference is not statistically significant. This lack of transparency is probably due to the fact that the central banks that classified themselves as inflation targeters had not all adopted full-fledged inflation targeting. All in all, Table 3 shows that forecast transparency is more common for inflation targeters, which helps them to explain their distinctively forward-looking and information-inclusive approach to the conduct of monetary policy.

Nevertheless, inflation targeters differ considerably in the choice and format of the forecasts they report (see Schmidt-Hebbel and Tapia 2002, Table 9). Although there is a lot of variety in transparency practices, one central bank has definitely been a trendsetter in economic transparency, namely the Bank of England. Its monetary policy framework and communication strategy have served as a template for several countries that have adopted inflation targeting (e.g. Brazil).

In practice, central banks tend to communicate economic conditions in a regular 'inflation report' or bulletin that provides an elaborate review of macroeconomic developments and typically also discusses the macroeconomic outlook. Under monetary targeting, special attention is given to money market conditions, whereas inflation targeters systematically analyze the determinants of inflation, including aggregate demand and supply. The quality of information varies noticeably, as is shown in the evaluation of inflation reports of inflation targeters by Fracasso et al. (2003). Interestingly, they find that higher quality inflation reports are associated with smaller market reactions to monetary policy decisions, which suggests that they lead to better predictability of policy actions. 
However, the inflation report does not necessarily reflect the latest policy decision. Although many central banks issue their inflation report within a week of a monetary policy decision, for a significant number of countries the monetary policy meeting and the publication of the inflation report are independent events (Schmidt-Hebbel and Tapia 2002, Tables 16-18). This greatly reduces the usefulness of these reports to understand monetary policy actions and infer the central bank's intentions.

Another issue is the frequency with which inflation reports or bulletins are published. Most inflation targeters have quarterly reports, but several central banks only publish every four months (Chile, Norway, Peru) or every half year (Israel, Korea, South Africa). It is desirable to publish the inflation report and macroeconomic forecasts in synch with the release of national accounts data. Since the national accounts are generally released at quarterly frequency ${ }^{12}$, a completely new set of macroeconomic data becomes available every quarter, which is likely to affect the central bank's forecasts. So, transparency requires that the inflation report be published at quarterly frequency as well.

In theory, inflation forecasts play a special role in inflation targeting and are sometimes even considered an intermediate target. In fact, inflation targeting implies inflation forecast targeting when the model of the economy is linear and the monetary policy loss function is quadratic (so that certainty equivalence applies) (Svensson 1997). Since inflation forecasts are a key determinant of monetary policy under inflation targeting, their publication is critical for transparency. Indeed, all 21 inflation targeters analyzed by Fracasso et al. (2003, Table 1.2) regularly publish inflation forecasts. These forecasts could be econometric projections prepared by central bank staff, but often they also incorporate the viewpoints of the monetary policymaker(s). The horizon of the forecasts tends to be two years, which approximately corresponds to the transmission lag from the policy rate to inflation (Schmidt-Hebbel and Tapia 2002, Table 9).

It is important for the central bank to form its own forecasts based on a structural macroeconomic model, because solely relying on the information contained in unconditional private sector (inflation) forecasts would be problematic and is likely to lead to indeterminacy in rational expectations models, as shown by Bernanke and Woodford (1997). In practice, many central banks make use of measures of inflation expectations (Fry et al. 2000, Table 4.8), which could be derived from financial market information (for $45 \%$ of central banks), or based on surveys of the private sector (for 43\%) or outside forecasters (for 39\%). Furthermore, 62\% of central banks use structural macroeconomic models and forecasts (Fry et al. 2000, Table 4.9). However, the central bank's policy models are not always published. Six out of the nine major central banks analyzed by Eijffinger and Geraats (2004) disclose their formal macroeconomic model that is used for policy analysis, including the Federal Reserve and the ECB, but not the Bank of Japan. A few central banks (e.g. the Bank of England) even make the computer code available online. Transparency about the central bank's policy model helps to substantiate its macroeconomic forecasts. It could also contribute to a better comprehension of the economy and thereby further reduce macroeconomic uncertainty.

Generally, the central bank's inflation forecasts are not sufficient to understand monetary

\footnotetext{
${ }^{12}$ Chile is an exception with monthly national accounts data.
} 
policy. When the central bank is concerned about both inflation and output stabilization, output forecasts are also an important input into the policy decision. In addition, the output gap determines 'demand pull' inflation and thereby plays a central role in the transmission of monetary policy through aggregate demand. In practice, many inflation targeters also publish their output growth forecasts, but central bank forecasts of the output gap are not so common (Mishkin 2004, Table 1).

To correctly interpret central bank forecasts it is important to know the assumptions they are based on, especially for the path of the policy instrument. Central banks that publish quantitative forecasts often assume that the policy rate remains constant (for some period of time), so that inflation and output forecasts provide an intuitive indicator of the need to adjust the policy rate. An increasingly popular assumption (which has been used by the Bank of England since 1998) is that the policy rate follows the time-varying path of market expectations implied by asset prices such as interest rate futures. This has the advantage that the policy rate assumption is consistent with current asset prices and their expectations, so there is no need to incorporate (highly uncertain) financial market reactions to deviations in the policy rate from market expectations. As a consequence, such forecasts are likely to provide a more accurate indicator for the determination of the policy stance in relation to market expectations. ${ }^{13}$ Theoretically more elegant is the assumption (first adopted by the Reserve Bank of New Zealand) that the policy rate corresponds to the projected optimal path, which leads to forecasts that are 'unconditional' in the sense that they are based on an endogenous policy rate, although they still depend on auxiliary assumptions for some other variables (e.g. oil prices).

In some countries (e.g. New Zealand, Norway) the central bank provides macroeconomic projections for alternative scenarios, which also gives an indication of the uncertainties associated with the projections. Several central banks present a more general assessment of risks to forecasts in the form of 'fan charts' that graphically illustrate confidence bands associated with the projection. They were first introduced by the Bank of England and are now used by 12 (out of 20) inflation targeters (Fracasso et al. 2003, Table 3.6). Openness about the risks to forecasts is important because they indicate the uncertainties surrounding monetary policy outcomes. In addition, in the absence of certainty equivalence, not only the level but also the risks to medium term macroeconomic forecasts are needed to determine optimal monetary policy settings.

The central bank's macroeconomic forecasts matter for two reasons. Medium run forecasts provide information about the anticipated economic disturbances that the central bank responds to, and changes to short run forecasts are informative about unanticipated transmission shocks that cause monetary policy outcomes to deviate from the central bank's intentions.

First, disclosure of the economic disturbances to which the central bank responds allows the public to use the monetary policy actions to infer the central bank's intentions. This leads to a beneficial information effect that reduces uncertainty about the central bank's commitment to its objectives and enhances the credibility of monetary policy. Furthermore, it has a positive incentive effect because it makes monetary policy actions a more reliable signal of the central bank's

\footnotetext{
${ }^{13}$ Indeterminacy problems à la Bernanke and Woodford (1997) should not be an issue provided the macroeconomic forecasts conditional on market expectations of the policy rate are founded on a structural macroeconomic model.
} 
intentions. This makes private sector inflation expectations more sensitive to changes in the policy instrument that cannot be explained by the anticipated shocks, which induces the central bank to invest in reputation and reduce the inflation bias (Geraats 2005b). When the transmission mechanism incorporates the adjustment of inflation expectations, transparency about anticipated economic shocks could even completely eliminate the inflation bias (Geraats 2001). Transparency also makes private sector expectations less sensitive to anticipated monetary policy actions, which could give the central bank greater flexibility to respond to economic disturbances without affecting inflation expectations (Geraats 2000). These beneficial effects of transparency even apply when the central bank does not have superior economic information.

Second, changes to short run macroeconomic forecasts contain information about unanticipated transmission disturbances. Transparency about such shocks gives rise to a beneficial incentive effect as it makes policy outcomes a better signal of the intentions of the central bank, which again leads to a reputation effect that reduces the inflation bias (Faust and Svensson 2001).

In addition to these benefits, the publication of unconditional forecasts could have a positive information effect and reduce private sector uncertainty about macroeconomic outcomes. However, transparency about economic information could also have harmful information effects. When supply or transmission shocks are disclosed, the public could incorporate them into its inflation expectations, which leads to greater inflation volatility and hampers output stabilization (Cukierman 2001, Jensen 2002). Furthermore, there could be damaging incentive effects that increase economic and financial volatility when the public information is noisy and agents put too much weight on it to coordinate their actions (Morris and Shin 2002).

These detrimental effects may explain why some central banks are reluctant to be more forthcoming about their forecasts. Nevertheless, there is econometric evidence that the publication of forecasts is beneficial. Using the Fry et al. (2000) survey data, Chortareas et al. (2002) show that the publication of more detailed forecasts reduces average inflation in a sample of 82 countries, even after controlling for macroeconomic characteristics such as GDP per capita, openness, political stability, exchange rate regime, and central bank independence. However, this does not hold for countries with an exchange rate peg, which is consistent with the fact that the reputation effect only applies in the presence of discretion and could explain the lower forecast transparency among exchange rate targeters. In addition, the lower level of inflation due to greater forecast transparency does not appear to come at the cost of greater output volatility.

To summarize, transparency about forward-looking analysis is widespread among central banks, but the publication of frequent forecasts, quantitative projections, risks to forecasts and forecast errors are each much less common. In addition, exchange rate targeters tend to exhibit slightly less forecast transparency, whereas inflation targeters often display significantly more.

\subsection{Strategy and Decision-Making}

The monetary policy strategy conceptually describes the procedure for monetary policymaking. It explains how economic information is used to set the monetary policy instruments to reach the monetary policy objectives. A significant number of central banks publish their monetary policy 
strategy nowadays, which is largely due to the popularity of explicit inflation targeting. The typical monetary policy strategy of inflation targeters amounts to setting the policy rate so that the medium run (central bank) inflation forecast is consistent with the inflation target. Another example is the self-branded 'two-pillar strategy' of the ECB, whereas the Federal Reserve and the Bank of Japan do not publish their strategy. The chief advantage of an explicit monetary policy strategy is that it reduces private sector uncertainty about the policymaking process and makes monetary policy actions more predictable.

It is sometimes argued that monetary policy strategies differ in terms of transparency. In particular, exchange rate targeting is considered very transparent whereas monetary targeting tends to be regarded as more opaque. Much of this discussion is misguided since transparency is not an inherent feature of the monetary policy strategy but the result of the central bank's communication policy. In principle, any monetary policy strategy could achieve transparency with sufficient communication efforts. However, the amount and type of information that needs to be communicated to achieve transparency does depend on the monetary policy strategy. In particular, with exchange rate targeting it is easy to understand monetary policy actions, but the prediction of the inflation outcome requires additional information, namely forecasts of foreign inflation and the change in the real exchange rate. In the case of monetary targeting, money market shocks are important for policy settings and outcomes. Inflation targeting distinguishes itself from other monetary policy strategies because of its information-inclusive approach that imposes high demands on the ability of the central bank to effectively communicate all the relevant information. Clearly, the communication policy needed to achieve transparency differs across monetary policy strategies.

For most central banks, the monetary policy strategy does not provide a mechanical rule for the setting of the policy instrument, with the exception of an exchange rate peg. When the strategy leaves considerable discretion, transparency about decision-making also requires the disclosure of details about how the monetary policy decision was taken, including minutes of monetary policy meetings and voting records (if any). So, the lack of discretion under exchange rate targeting helps to explain why the publication of minutes and voting records is so rare for this monetary policy framework.

In most countries, monetary policy decisions are made by a committee of monetary policymakers. The minutes of their policy meetings give valuable insights into the arguments that were raised and the considerations that drove the policy decision. It allows the public to analyze how monetary policymakers incorporate economic information to form their policy stance, which leads to a better understanding of the implementation of the monetary policy strategy. This could help to increase the predictability of monetary policy actions. In practice, only $18 \%$ of countries release minutes of monetary policy meetings, although $60 \%$ of inflation targeters do so (see Table 1). The publication of voting records is even less common, with fewer than $10 \%$ of central banks and $20 \%$ of inflation targeters. Major central banks that publish minutes and voting records include the Federal Reserve, Bank of Japan and Bank of England, but not the ECB.

However, in some countries monetary policy decisions are made solely by the central bank 
governor, which means that there are no minutes or voting records. Although the Fry et al. (2000) data do not specify whether monetary policy decisions are made by the governor, out of the 21 inflation targeters considered by Fracasso et al. (2003, Table 1.2), only 2 (Israel and New Zealand) leave monetary policy decisions to the central bank governor instead of a committee. If this prevalence of decision making by committee extends to other monetary policy frameworks, Table 1 slightly understates the fraction of central banks that publish their minutes and release their voting records.

When monetary policy actions are determined by a single central banker, transparency about decision making requires detailed policy explanations instead of minutes. In either case, they should contain an account of the main arguments that were considered during the decision process. It is also important that they are published as soon after the monetary policy decision as is practicably possible and at the latest before the subsequent policy decision. This allows the private sector to gain a better understanding of the most recent monetary policy action, which could help to predict subsequent policy decisions.

In practice, publication delays vary widely. Using the Fry et al. (2000, Appendix 1) survey data, $12 \%$ of central banks publish minutes within a month of the monetary policy meeting. The Federal Reserve recently decided to publish its minutes three weeks after the monetary policy meeting instead of after the next meeting, which is still the practice of the Bank of Japan. For inflation targeters, 7 (out of 19) central banks publish minutes, with a delay ranging from about a week to several months, and 4 of them (Brazil, Czech Republic, Sweden and the United Kingdom) release the minutes before the next monetary policy meeting (Schmidt-Hebbel and Tapia 2002, Tables 15 and 20). This shows that timely information about policy discussions is not very common.

The minutes that central banks publish tend to be non-verbatim and unattributed, although there are a few exceptions. For instance, the minutes of the Swedish Riksbank feature an attributed reservation by each member of the monetary policy committee that disagrees with the policy decision. And the minutes of the Bank of Japan explicitly identify the remarks made by government representatives attending the monetary policy meeting. The publication of verbatim transcripts is extremely rare. An exception is the Federal Reserve, which has been forced to release them but only with a five-year delay.

The disclosure of voting records is remarkably uncommon. Table 1 shows that only a third of central banks that publish minutes also release voting records. The only countries in the Fry et al. (2000) survey that publish voting patterns are Japan, Korea, Poland, Sweden, the United Kingdom and the United States. The voting records could be released as part of the minutes of the monetary policy meeting (e.g. Japan and UK) or together with the announcement of the monetary policy decision, a practice recently adopted by the Federal Reserve.

One issue with voting records is that some central banks (e.g. the ECB) state that the monetary policy committee decides 'by consensus'. ${ }^{14}$ It is not exactly clear what this involves because consensus need not imply unanimity. Instead, it could mean that there were no strong objections

\footnotetext{
${ }^{14}$ Some other communication issues for such 'collegial' rather than 'individualistic' monetary policy committees are discussed by Blinder and Wyplosz (2005).
} 
against the decision, or that a large majority of policymakers agreed with the decision. In any case, decision making by consensus is opaque about the policy actions preferred by individual central bankers. Moreover, it is inconsistent with the statutes of many central banks (including the ECB) that stipulate that decisions be taken by a simple majority. Since consensus decisions require more than a simply majority, they are likely to lead to much more sluggish decision making.

In theory, the publication of minutes has a beneficial information effect as it reduces private sector uncertainty about the policy decision process. It is also likely to have a positive effect on the central bank's incentive to conduct high quality policy discussions. However, the publication of verbatim, attributed transcripts of monetary policy meetings could induce a detrimental incentive effect because it is likely to make policymakers more guarded out of concern that their words may be misinterpreted by financial markets. In addition, it could make central bankers with career concerns reluctant to offer dissenting opinions, which is supported by empirical evidence (Meade and Stasavage 2004). So, live broadcasts or the release of verbatim transcripts of monetary policy meetings are undesirable because they hamper an open policy discussion, which reduces the efficiency of the decision process and the quality of monetary policy decisions. But this problem does not arise for the unattributed minutes with a sanitized account of the policy discussion that central banks tend to publish in practice.

Regarding the publication of attributed voting records, there is a beneficial information effect since it allows the public to observe the monetary policy stance of individual central bankers and thereby better predict future monetary policy actions. There is empirical evidence that voting records are indeed informative about future policy decisions (Gerlach-Kristen 2004). Another positive information effect is that voting transparency could identify central bankers with socially desirable preferences so that they can be reappointed (Gersbach and Hahn 2004).

However, the publication of individual voting records also has incentive effects. In particular, 'doves' in the monetary policy committee that vote for inflationary actions would be exposed, which could induce them to build reputation by voting as an anti-inflationary 'hawk' (Sibert 2003). On the other hand, voting transparency could affect monetary policy votes in a negative way. Monetary policymakers could be tempted to vote according to the wishes of the government that reappoints them, which is detrimental when the government favors inflationary policy. Similarly, voting opacity could be desirable for a monetary union in which central bank reappointments are made by national governments, as is the case for the ECB (Gersbach and Hahn 2005).

This suggests that the desirability of voting transparency may depend on the (re)appointment process for central bankers. The beneficial reputation effect is likely to be stronger when central bankers have a longer term of office, whereas the detrimental incentive effects hinge on renewable terms for central bankers. So, when central bankers have a long term of office without the possibility of reappointment, voting transparency is likely beneficial as it reduces private sector uncertainty about the policy stance. On the other hand, central bankers that are subject to reappointment could embrace voting secrecy to protect themselves from political pressures. Perhaps, this helps to explain why the release of voting records is so rare in practice. 
Table 4: Policy transparency across and within monetary policy frameworks.

\begin{tabular}{|c|c|c|c|c|c|c|}
\hline \multirow[t]{2}{*}{ Relative frequency } & \multirow[t]{2}{*}{ Full sample } & \multicolumn{3}{|c|}{ Targeting } & \multirow[t]{2}{*}{ Other } & \multirow{2}{*}{$\begin{array}{l}\text { Homogeneity } \\
\text { rejected }^{a}\end{array}$} \\
\hline & & Exch. rate & Money & Inflation & & \\
\hline \multicolumn{7}{|l|}{ Publication of explanation } \\
\hline Policy changes & 0.809 & 0.808 & 0.696 & 0.933 & 0.833 & $* *$ \\
\hline All policy decisions ${ }^{b}$ & 0.154 & 0.042 & 0.261 & 0.267 & 0.103 & $* *$ \\
\hline Observations & $94\left(91^{b}\right)$ & $26\left(24^{b}\right)$ & 23 & 15 & $30\left(29^{b}\right)$ & \\
\hline
\end{tabular}

Source: Author's calculations using Fry et al. (2000) survey data.

Note: Numbers in bold are over 10 percent point different from the full sample relative frequency.

(a) $\chi_{1}^{2}$ test of homogeneity between monetary policy frameworks rejected at a (**) $5 \%$ significance level.

(b) Missing observations for Denmark, EMU and Singapore.

\subsection{Policy Stance}

The monetary policy stance is the outcome of the decision-making process. It consists of a monetary policy action that sets the level of the policy instrument and a policy inclination that describes how policymakers are inclined to move beyond the current policy action.

Many central banks make their monetary policy decisions at regular meetings according to an announced schedule. Knowing the dates of policy meetings in advance reduces private sector uncertainty and is likely to lead to greater stability as financial markets only have to brace themselves for monetary policy actions on a limited number of days.

Monetary policy decisions specify the settings of operating instruments or targets. Many central banks use a short run nominal interest rate such as the overnight interbank rate or a repo rate as their policy rate. ${ }^{15}$ But in developing countries the use of a monetary aggregate is more common because the presence of an underdeveloped financial system complicates the use of market-based implementation of a policy rate. The decision to adjust the setting of the operating instrument or target is promptly announced by over $80 \%$ of central banks (see Table 4). Transparency about policy changes is nowadays almost taken for granted, but this has not always been the case. For instance, the Federal Reserve only adopted this practice in 1994 instead of keeping changes in the federal funds rate target secret until the next policy meeting.

Typically, central banks adjust their operating instrument or target in discrete steps. In particular, the minimum step for policy rates tends to be 25 basis points. As a consequence, central banks regularly decide at the monetary policy meeting not to adjust the policy instrument or target. However, few central banks provide an explanation of the monetary policy decision when the policy settings are not adjusted. Table 4 shows that only $15 \%$ of central banks publish an explanation for all policy decisions, even when there is no change in policy settings. For example, the Bank of England and Bank of Japan only tend to provide an immediate explanation in case of policy changes. But transparency requires that all monetary policy decisions are ex-

\footnotetext{
${ }^{15}$ Chile is an exception as it controls the real interbank rate. In addition, Mexico is the only inflation targeting country to use a monetary aggregate, the 'corto' (short position), as its policy instrument.
} 
plained because it helps the private sector to better understand how the central banks determines its policy settings. After all, new economic information has arrived since the previous policy meetings, so no change in policy settings could be just as important and informative as a policy adjustment.

There is some variation across monetary policy frameworks in the degree of transparency about policy decisions, as is shown in Table 4. In particular, exchange rate targeters mostly confine themselves to explaining policy changes and are less likely than others to explain decisions involving no policy change. In contrast, money and inflation targeters have a relative frequency of explanations for all policy decisions that is high above the average for the full sample. The difference between exchange rate targeters and the aggregate of monetary and inflation targeters is statistically significant. Probably, the limited discretion under fixed exchange rates reduces the need for explaining no-policy-change decisions.

However, transparency of the monetary policy stance requires more than publishing explanations of all policy actions. Since policy rates tend to be adjusted in discrete steps, they do not provide a precise indicator of the policy stance. For instance, if the desired policy rate equals $3.1 \%$, the policy setting is typically rounded to $3 \%$. So, there is an important role for a policy 'tilt', 'bias' or 'inclination' that conveys some of this information about the policy stance.

An even more elaborate indicator of the policy stance is the time path of the policy rate that is considered optimal by the central bank. This is not only useful for the prediction of future interest rates but it is also critical for figuring out the likely macroeconomic effects of monetary policy. In particular, a change in the policy rate that is anticipated to be persistent has a bigger impact on long term interest rates and is therefore more effective in affecting macroeconomic outcomes than an adjustment of the policy rate that only lasts, say, one quarter. So, the projected time path of the policy rate is a crucial component of the monetary policy stance.

In practice, the publication of a policy inclination or projection is not common. Using the Eijffinger and Geraats (2004) data for nine major central banks, two provide a policy inclination (the Federal Reserve and Swedish Riksbank) and only one (the Reserve Bank of New Zealand) publishes policy rate projections.

The disclosure of a policy inclination allows the private sector to observe the current policy stance more accurately. This has a beneficial information effect as it facilitates the understanding of monetary policymaking and increases the predictability of future policy actions.

However, the publication of an optimal policy rate path could also give rise to a detrimental incentive effect when financial market participants decide to ignore their private signals and coordinate their actions on the published policy path (cf Morris and Shin 2002). The reason is that the central bank's policy projection could be quite noisy compared to private sector information because the optimal path for the policy rate depends on the market reactions to policy settings, about which financial market participants are likely to have better information than the central bank. So, excessive focus on the central bank's policy projection could lead to greater volatility in financial markets.

Another issue is the challenge to communicate effectively that the projected policy path or inclination does not constitute a commitment to specific future policy decisions. Instead, 
it is a projection that is conditional on the information currently available and it is bound to adjust in response to new economic information. Perhaps, these complications explain why the publication of policy inclinations or projections is so rare.

It is sometimes argued that voting patterns or risks to the central bank's forecasts provide an indication of the policy inclination. However, neither is a perfect substitute. For instance, suppose that all central bankers agree that the desired policy rate is $3.1 \%$ and therefore decide to leave the policy rate at $3 \%$. Then the voting records would not reveal the positive policy inclination. In fact, voting patterns would only correctly reveal the policy tilt if the distribution of desired policy rates across policymakers is sufficiently wide and symmetric. Regarding risks to forecasts, suppose there is an upward risk to the inflation forecast and a downward risk to the output forecast. Then it is not straightforward to infer the policy inclination. These examples illustrate that the publication of the policy inclination is not redundant when voting patterns and risks to forecasts are released.

\section{Additional Considerations}

There are two additional considerations that are important for understanding the practice of monetary policy transparency. First, central banks may be forced to disclose information to meet formal accountability requirements. Second, a central bank may not be able to be as transparent as it intends because of challenges associated with the effective communication of information.

\subsection{Accountability}

In general, accountability requires transparency about at least the institutional setting and the formal objectives, so that it is clear who should be held responsible and for what. As discussed in section 4.1, many central banks enjoy a considerable degree of independence and nearly all have explicit targets nowadays. Although instrument independence is common, goal independence is more unusual since the government has a role in setting the target for $71 \%$ of central banks (Fry et al. 2000, Table 4.5). This reduces the democratic deficit that arises from the delegation of the conduct of monetary policy to an independent central bank. Another way to ensure democratic legitimacy is to shift the final responsibility for monetary policy to government by allowing it to overrule monetary policy decisions through a formal override mechanism. In theory, this impinges on the independence of the central bank, which is likely to lead to higher inflation, but it increases the flexibility to respond to shocks (Lohmann 1992). An explicit override mechanism exists in $21 \%$ of countries (Fry et al. 2000, Table 4.5), including the United Kingdom and New Zealand, although in practice it is rarely invoked.

Accountability of monetary policy typically requires additional transparency besides institutional arrangements and explicit objectives. One reason is that monetary policy decisions are often made by a committee. If the monetary policymakers face individual rather than collective responsibility, the publication of individual voting records is also pertinent to accountability. But in practice, very few central banks release voting records, as discussed in section 4.3. 
Furthermore, depending on the monetary policy framework, it may not be possible to control the targeted variable perfectly and without delay. In particular, the performance of an exchange rate targeter is easy to monitor because the exchange rate can be directly controlled as long as foreign reserves are sufficient. But, the evaluation of a central bank engaged in monetary targeting is more complicated because the central bank typically does not have perfect control over the targeted monetary aggregates. So, monetary control errors due to unanticipated developments in money markets need to be taken into account.

The assessment of an inflation targeter is even more challenging. Monetary policymakers cannot perfectly control inflation due to unpredictable transmission disturbances, such as oil shocks and terror attacks. In addition, there is a long transmission lag of one to two years from the change in the monetary policy instrument to its effect on inflation. So, current inflation outcomes reflect past policy decisions and cannot be used to assess the appropriateness of the current policy stance. To achieve accountability in real time it is necessary to evaluate whether monetary policy actions are likely to achieve the inflation target. As a result, transparency about the central bank's inflation forecasts is a key ingredient for effective accountability under inflation targeting. But the inflation forecast is not a sufficient statistic; comprehensive macroeconomic information is needed because of the information-inclusive approach of inflation targeters.

Clearly, accountability requires greater transparency under inflation targeting than under exchange rate targeting. This could be another reason why inflation targeters tend to be more transparent than exchange rate targeters, as shown in Table 1. However, the formal disclosure requirements that central banks are subject to tend to be insufficient to adequately assess the appropriateness of monetary policy actions. Moreover, the public communications of most central banks by far exceed their legal requirements, which suggests that formal accountability is not the main motivation for transparency.

In practice, monetary policy accountability mostly takes the form of parliamentary monitoring, which typically involves regular testimonies by central bankers. The central bank is subject to monitoring by the legislature in $74 \%$ of countries (Fry et al. 2000, Table 4.5). In addition, $18 \%$ of central banks face formal procedures when the target is missed. For instance, the central bank could be required to provide a written explanation for the deviation from the target. In a few cases, the sanctions could be more draconian. For example, the governor of the Reserve Bank of New Zealand could be fired if the inflation target is missed. A more proactive approach to accountability is to assess the reliability of the monetary policymaking process through an evaluation of the monetary policy framework by external experts as has been done in New Zealand, Norway and the United Kingdom.

These accountability provisions are likely to provide a direct incentive to improve monetary policymaking. In addition, accountability could be important to maintain public support for central bank independence. This suggests that accountability has intrinsic benefits.

Although accountability could directly affect transparency through formal disclosure requirements and public testimonies, the increase in monetary policy transparency over time (described by stylized fact II) has typically not been the result of modifications to central bank accountability. But accountability could induce improvements in central bank transparency with- 
out formal disclosure requirements. For instance, (nonbinding) European Parliament resolutions on the ECB Annual Report have repeatedly urged the ECB to be become more transparent, and the publication of the ECB's macroeconomic projections appears to have been triggered by the quarterly 'monetary dialogue' between the ECB and the European Parliament Committee on Economic and Monetary Affairs (based on Article 113(3) of the Treaty on European Union). Nevertheless, central banks would probably be prepared to withstand such outside pressures if the greater openness were considered to be damaging. In fact, the Federal Reserve vigorously countered some legal challenges to its secrecy (Merrill vs Federal Open Market Committee, which is discussed by Goodfriend 1986).

These considerations suggest that accountability is unlikely to be the main driving force behind central bank transparency.

\subsection{Communication Challenges}

While accountability requirements could force a central bank to disclose information and be transparent against its will, central banks could also be involuntarily opaque. Although such a situation might occur due to confidentiality requirements faced by central banks, in practice it is much more likely to arise because of challenges in the effective communication of information.

One of the main reasons why there exists a big gap between the theory and practice of transparency is that the theoretical literature tends to abstract from the complications that arise when central banks attempt to reduce information asymmetries through communications. Most transparency models simply assume that information somehow gets perfectly conveyed. In fact, some models do not even have explicit announcements. However, in practice it is not trivial to communicate information effectively and there is a lot of scope for misinterpretation.

From a practical perspective, transparency is better understood in terms of openness, clarity and common understanding (Winkler 2002). Transparency does not merely amount to complete openness in the sense of disclosing all information. The reason is that agents are constrained by limited resources, so flooding them with data may not help them to extract the relevant information. To obtain symmetric information it is important to communicate with clarity and reach common understanding about the monetary policy process.

There is inevitably some friction between openness and clarity. For instance, an elaborate description of the policy stance may be more accurate, but a stylized summary is likely to provide greater clarity. This also explains why some central banks resort to the use of standard phrases. When the meaning of such phrases is commonly understood, it greatly facilitates effective communication.

This also underscores the importance of an active communication policy. To achieve transparency, the central bank should carefully identify what information is most useful for understanding monetary policymaking, and how to communicate it effectively. A framework of regular publications (e.g. policy statements, inflation reports, minutes) provides an institutional commitment to the communication strategy. Since such publications are known to receive central attention, they also foster common knowledge about monetary policy. 
Central bank communications are a critical tool in addition to monetary policy instruments. The latter directly affect short term (nominal) interest rates, whereas the former have the potential to influence private sector expectations about future policy rates and inflation. These expectations determine the long term and real interest rates that matter most for economic decisions.

Although central bank communications could greatly facilitate the conduct of monetary policy, there is also scope for misinterpretations and overreactions that could roil financial markets. To reduce the likelihood of overreactions, central bankers may decide to avoid straight talk and use 'constructive ambiguity' instead. In fact, creating the perception of opacity could even be the optimal way to communicate information (Geraats 2005a).

There could be other reasons for vague communications. When announcements are costless or 'cheap talk', a central bank can only credibly convey its private information through imprecise announcements (Stein 1989). In practice, however, central bank communications are a valuable tool in the conduct of monetary policy that is open to public scrutiny, and with the central bank's reputation at stake, it is far from cheap.

Furthermore, sometimes it can be very difficult to be precise. The communication of uncertainty is particularly challenging because of the innumerable sources of incomplete information. Nevertheless, it is important for the central bank to convey uncertainty, especially when it affects monetary policy decisions. Otherwise, the central bank's inaction due to uncertainty could lead to doubts about its intentions. Although it is impossible to specify all uncertainties the central bank faces, the most relevant ones could be usefully communicated through 'scenarios' that describe specific risks and 'confidence intervals' around numeric projections that illustrate more generally the (possibly skewed) balance of risks.

The precise communication needs of a central bank are determined by its monetary policy strategy. Empirically, the type of information disclosed by central banks is systematically related to the monetary policy framework, as shown in section 4. Although some communication policies may be better than others, in practice different communication strategies could be equally effective in terms of financial market responses and the predictability of monetary policy actions (Ehrmann and Fratzscher 2005). This suggests that there is more than one way in which communication challenges could be successfully overcome.

\section{Conclusions}

Transparency has gradually become a prominent characteristic of monetary policy throughout the world. This paper systematically explores transparency practices and reconciles them with theoretical insights. The theory is distilled into two effects that drive the economic consequences of transparency, namely ex post 'information effects' that directly result from the conferral of information, and ex ante 'incentive effects' that are caused by systematic changes in economic behavior under the different information structure. Three key theoretical results are that monetary policy transparency (A) improves the predictability of monetary policy actions and outcomes, (B) induces reputation building as it increases the sensitivity of private sector expectations to 
unanticipated policy actions and outcomes, and (C) enhances credibility and makes long-run private sector inflation expectations more stable.

The main contribution of this paper has been to present three stylized facts on the practice of monetary policy transparency. In particular, the paper has established that (I) central banks consider transparency very important for monetary policy, (II) transparency of monetary policy has increased remarkably during the last 15 years, and (III) monetary policy transparency displays substantial heterogeneity both across and within monetary policy frameworks.

Regarding the heterogeneity in transparency of monetary policy, most countries are reasonably transparent about central bank independence, monetary policy targets, forward-looking analysis and explanations of policy changes. At the same time, they tend to be very opaque about minutes, voting records and explanations of no-policy-change decisions.

Furthermore, there are also three significant differences in transparency across monetary policy frameworks. First, central banks that do not engage in exchange rate, money or inflation targeting are less likely to publish an explicit target, which reflects the central role of announced targets for targeting regimes. Second, inflation and money targeters are more likely to be transparent about forecasts than exchange rate targeters and others without an explicit targeting framework. Third, inflation targeters are more likely to display greater openness with respect to forecasts, minutes and voting records. This may be explained by the forward-looking, information-inclusive approach to monetary policymaking that characterizes inflation targeting.

Although transparency tends to be more common for inflation targeters, the adoption of inflation targeting does not guarantee transparency in all respects. In addition, there is remarkable variation in the degree of central bank transparency under inflation targeting as well as under other monetary policy frameworks.

Transparency practices do not seem to be primarily driven by accountability requirements. Instead, central banks appear to have embraced transparency for its perceived economic benefits. In particular, empirical evidence shows that monetary policy transparency could lead to greater predictability of policy actions, reduce average inflation and lower the sacrifice ratio. However, many communication challenges remain and central banks are likely to continue their efforts to pursue greater transparency of monetary policy in practice. 


\section{References}

Bernanke, B. S., Laubach, T., Mishkin, F. S. and Posen, A. S. (1999), Inflation Targeting: Lessons from the International Experience, Princeton University Press, Princeton, New Jersey.

Bernanke, B. S. and Woodford, M. (1997), 'Inflation forecasts and monetary policy', Journal of Money, Credit, and Banking 29(4), 653-686.

Blinder, A., Goodhart, C., Hildebrand, P., Lipton, D. and Wyplosz, C. (2001), 'How do central banks talk?', Geneva Report on the World Economy 3, ICMB.

Blinder, A. S. (1997), 'What central bankers could learn from academics - and vice versa', Journal of Economic Perspectives 11(2), 3-19.

Blinder, A. S. (2000), 'Central-bank credibility: Why do we care? how do we build it?', American Economic Review 90(5), 1421-1431.

Blinder, A. S. and Wyplosz, C. (2005), 'Central bank talk: Committee structure and communication policy', Paper presented at the AEA Annual Meeting in Philadelphia, January 2005.

Cecchetti, S. G. and Ehrmann, M. (2002), Does inflation targeting increase output volatility? an international comparison of policymakers' preferences and outcomes, in N. Loayza and K. Schmidt-Hebbel, eds, 'Monetary Policy: Rules and Transmission Mechanisms', Vol. IV of Series on Central Banking, Analysis, and Economic Policies, Central Bank of Chile, pp. 247-274.

Chortareas, G., Stasavage, D. and Sterne, G. (2002), 'Does it pay to be transparent? International evidence from central bank forecasts', Federal Reserve Bank of St. Louis Review 84(4), 99117.

Chortareas, G., Stasavage, D. and Sterne, G. (2003), 'Does monetary policy transparency reduce disinflation costs?', The Manchester School 71(5), 521-540.

Cukierman, A. (2001), Accountability, credibility, transparency and stabilization policy in the eurosystem, in C. Wyplosz, ed., 'The Impact of EMU on Europe and the Developing Countries', Oxford University Press, chapter 3, pp. 40-75.

Cukierman, A. (2002), 'Are contemporary central banks transparent about economic models and objectives and what difference does it make?', Federal Reserve Bank of St. Louis Review 84(4), 15-35.

Ehrmann, M. and Fratzscher, M. (2005), 'Central bank communication: Different strategies, same effectiveness?', ECB Working Paper 488. 
Eijffinger, S. C. and Geraats, P. M. (2004), 'How transparent are central banks?', Cambridge Working Papers in Economics 0411.

Faust, J. and Svensson, L. E. (2001), 'Transparency and credibility: Monetary policy with unobservable goals', International Economic Review 42(2), 369-397.

Fracasso, A., Genberg, H. and Wyplosz, C. (2003), How Do Central Banks Write? An Evaluation of Inflation Targeting Central Banks, Vol. Special Report 2 of Geneva Reports on the World Economy, Centre for Economic Policy Research.

Fry, M., Julius, D., Mahadeva, L., Roger, S. and Sterne, G. (2000), Key issues in the choice of monetary policy framework, in L. Mahadeva and G. Sterne, eds, 'Monetary Policy Frameworks in a Global Context', Routledge, London, pp. 1-216.

Gai, P. and Shin, H. S. (2003), 'Transparency and financial stability', Bank of England Financial Stability Review 15, 91-98.

Geraats, P. M. (1999), 'Inflation and its variation: An alternative explanation', CIDER Working Paper C99-105, University of California, Berkeley.

Geraats, P. M. (2000), 'Why adopt transparency? The publication of central bank forecasts', CEPR Discussion Paper 2582.

Geraats, P. M. (2001), 'Precommitment, transparency and monetary policy', Bundesbank Discussion Paper 12/01.

Geraats, P. M. (2002), ‘Central bank transparency’, Economic Journal 112(483), F532-F565.

Geraats, P. M. (2005a), 'The mystique of central bank speak', mimeo, University of Cambridge.

Geraats, P. M. (2005b), 'Transparency and reputation: The publication of central bank forecasts', Topics in Macroeconomics 5(1.1), 1-26.

Gerlach-Kristen, P. (2004), 'Is the MPC's voting record informative about future UK monetary policy?', Scandinavian Journal of Economics 106(2), 299-313.

Gersbach, H. and Hahn, V. (2004), 'Voting transparency, conflicting interests, and the appointment of central bankers', Economics and Politics 16(3), 321-345.

Gersbach, H. and Hahn, V. (2005), 'Voting transparency in a monetary union', mimeo, University of Heidelberg. http://ssrn.com/abstract=757744.

Goodfriend, M. (1986), 'Monetary mystique: Secrecy and central banking', Journal of Monetary Economics 17(1), 63-92.

Jensen, H. (2002), 'Optimal degrees of transparency in monetary policymaking', Scandinavian Journal of Economics 104(3), 399-422. 
Kydland, F. E. and Prescott, E. C. (1977), 'Rules rather than discretion: The inconsistency of optimal plans', Journal of Political Economy 85(3), 473-491.

Lohmann, S. (1992), 'Optimal commitment in monetary policy: Credibility versus flexibility', American Economic Review 82(1), 273-286.

Meade, E. E. and Stasavage, D. (2004), 'Publicity of debate and the incentive to dissent: Evidence from the US federal reserve', CEP Discussion Paper 0608.

Mishkin, F. S. (2004), Can central bank transparency go too far?, in C. Kent and S. Guttmann, eds, 'The Future of Inflation Targeting', Reserve Bank of Australia, pp. 48-65.

Mishkin, F. S. and Schmidt-Hebbel, K. (2002), A decade of inflation targeting in the world: What do we know and what do we need to know?, in N. Loayza and R. Soto, eds, 'Inflation Targeting: Design, Performance, Challenges', Vol. V of Series on Central Banking, Analysis, and Economic Policies, Central Bank of Chile, pp. 171-219.

Morris, S. and Shin, H. S. (2002), 'Social value of public information', American Economic Review 92(5), 1521-1534.

Peek, J., Rosengren, E. S. and Tootell, G. M. B. (1999), 'Is bank supervision central to central banking?', Quarterly Journal of Economics 114(2), 629-653.

Rogoff, K. (1985), 'The optimal degree of commitment to an intermediate monetary target', Quarterly Journal of Economics 100(4), 1169-1189.

Romer, C. D. and Romer, D. H. (2000), 'Federal Reserve information and the behavior of interest rates', American Economic Review 90(3), 429-457.

Rudin, J. R. (1988), 'Central bank secrecy, 'Fed watching', and the predictability of interest rates', Journal of Monetary Economics 22(2), 317-334.

Schaechter, A., Stone, M. R. and Zelmer, M. (2000), 'Adopting inflation targeting: Practical issues for emerging market countries’, IMF Occasional Paper 2002.

Schmidt-Hebbel, K. and Tapia, M. (2002), 'Monetary policy implementation and results in twenty inflation-targeting countries', Central Bank of Chile Working Paper 166.

Shin, H. S. and Morris, S. (2005), 'Central bank transparency and the signal value of prices', mimeo, London School of Economics.

Sibert, A. (2003), 'Monetary policy committees: Individual and collective reputations', Review of Economic Studies 70(3), 649-665.

Sørensen, J. R. (1991), 'Political uncertainty and macroeconomic performance', Economics Letters 37(4), 377-381. 
Stein, J. C. (1989), 'Cheap talk and the fed: A theory of imprecise policy announcements', American Economic Review 79(1), 32-42.

Svensson, L. E. (1997), 'Inflation forecast targeting: Implementing and monitoring inflation targets', European Economic Review 41(6), 1111-1146.

Svensson, L. E. (2003), The inflation forecast and the loss function, in P. Mizen, ed., 'Central Banking, Monetary Theory and Practice: Essays in Honour of Charles Goodhart', Vol. I, Edward Elgar, chapter 4, pp. 135-152.

Swanson, E. T. (2004), 'Federal Reserve transparency and financial market forecasts of shortterm interest rates', Federal Reserve Board Finance and Economics Discussion Series 2004-6.

Tong, H. (2005), 'Disclosure standards and market efficiency: Evidence from analysts' forecasts', Paper presented at the AFA Annual Meeting in Philadelphia, January 2005.

van der Cruijsen, C. and Demertzis, M. (2005), 'The impact of central bank transparency on inflation expectations', Paper presented at the National Bank of Poland conference "Central Bank Transparency and Communication: Implications for Monetary Policy”, Warsaw, June 2-3, 2005.

Winkler, B. (2002), 'Which kind of transparency? On the need for effective communication in monetary policy-making', ifo Studien $\mathbf{4 8}(3)$, 401-427. 